\title{
FACTORS AFFECTING THE STAGNATION OF SAMPAN (SAPTA MITRA PANTURA) INTERREGIONAL COOPERATION
}

\author{
Tri Aji Pefridiyono, Jeremias T. Keban \\ Master of Urban and Regional Planning \\ Departement of Architecture and Planning, Universitas Gadjah Mada \\ Korespondensi: triaji12@gmail.com
}

\begin{abstract}
The problems of interregional cooperation emerged when the opportunities for interregional cooperation were more open, whereas the interregional cooperation that have been running actually stagnated in sustainability. SAMPAN is one of the interregional cooperations in Indonesia consisting of seven regions in Central Java. SAMPAN is an interregional cooperation in the field of regional management focusing on the development of the sectors of tourism, trade and investment. Even though SAMPAN stagnated since 2012, several studies related to SAMPAN suggested that interregional cooperation gave benefits for local regions. The research titled 'Factors Affecting the Stagnation of SAMPAN Interregional Cooperation' is a deductive qualitative research conducted by processing data obtained from interviews with stakeholders in the SAMPAN region. The main factor affecting the performance of SAMPAN is transformation of rules which implicated the mechanism of funding. Another factor is interdependency among members. This refered to the commitment of the executives (mayors or regents), especially related to the policy of cross-border development, including infrastructure development. The last factor is political will which came from legislature who has role in policy making in each region. Therefore, the consequences of all factors must be implemented in SAMPAN's funding.
\end{abstract}

Keywords: Factors, interregional cooperation.

\begin{abstract}
ABSTRAK
Permasalahan kerjasama antardaerah muncul saat peluang kerjasama antardaerah semakin terbuka, sedangkan kerjasama antardaerah yang telah berjalan justru mengalami stagnasi. SAMPAN merupakan salah satu kerjasama antardaerah di Indonesia yang terdiri dari tujuh wilayah di Jawa Tengah. SAMPAN adalah kerjasama antardaerah di bidang pengelolaan daerah yang fokus pada pengembangan sektor pariwisata, perdagangan dan investasi. Meski SAMPAN mengalami stagnasi sejak 2012, beberapa penelitian terkait SAMPAN mengemukakan bahwa kerjasama antardaerah memberi manfaat bagi daerah. Penelitian yang berjudul 'Faktor-faktor yang Mempengaruhi Stagnasi Kerjasama Antardaerah SAMPAN' adalah penelitian kualitatif deduktif yang dilakukan dengan mengolah data dan informasi yang diperoleh dari wawancara dengan pemangku kepentingan di wilayah SAMPAN. Faktor utama yang mempengaruhi kinerja SAMPAN adalah transformasi peraturan yang melibatkan mekanisme pendanaan. Faktor lainnya adalah interdependensi antar anggota. Ini mengacu pada komitmen para eksekutif (walikota atau bupati), terutama yang berkaitan dengan kebijakan pembangunan lintas batas, termasuk pembangunan infrastruktur. Faktor terakhir adalah kemauan politik dari legislatif yang juga berperan dalam pengambilan kebijakan di daerah. Oleh karena itu, konsekuensi dari faktor-faktor tersebut harus diimplementasikan dalam pendanaan SAMPAN.
\end{abstract}

Kata Kunci: Faktor, kerjasama antar daerah. 


\section{LATAR BELAKANG}

Ketentuan kerjasama antardaerah dipertahankan hingga era otonomi daerah dan diatur dalam undang-undang terakhir tentang Pemerintahan Daerah, UU No. 23 Tahun 2014 Bab XVII Kerjasama Daerah. Pasal 363 menyatakan bahwa untuk meningkatkan kesejahteraan, daerah dapat bekerjasama berdasarkan pertimbangan efisiensi dan efektivitas pelayanan publik serta saling menguntungkan. Undang-undang ini juga mengklasifikasikan kerjasama antardaerah menjadi kerjasama wajib dan kerjasama sukarela. Ini berarti bahwa kerjasama antardaerah harus dilaksanakan terutama dalam urusan pemerintahan yang memiliki eksternalitas lintas wilayah dan membutuhkan efisiensi dalam memberikan pelayanan publik.

Di Jawa Tengah, sampai 2009 setidaknya, telah terbentuk tiga kerjasama antardaerah, yaitu Subosukowonosraten, Barlingmascakeb dan SAMPAN. Salah satu kerjasama antardaerah di Jawa Tengah adalah SAMPAN. SAMPAN yang merupakan akronim Sapta Mitra Pantura, dibentuk pada tahun 2005 melalui penandatanganan Keputusan Bersama pada tanggal 7 Juni 2005 oleh tujuh kepala daerah (walikota dan bupati) di bagian barat wilayah pesisir utara Jawa Tengah, yaitu Kabupaten Batang, Kota Pekalongan, Kabupaten Pekalongan, Kabupaten Pemalang, Kota Tegal, Kabupaten Tegal dan Kabupaten Brebes.

Kerjasama antardaerah di Jawa Tengah memiliki banyak manfaat positif bagi daerah-daerah yang tergabung di dalamnya, baik ekonomi daerah maupun peningkatan pelayanan publik. Dalam bidang ekonomi regional, kerjasama antardaerah dapat menunjang kesejahteraan petani melalui pasar lelang. Nilai transaksi yang terjadi di setiap pasar lelang selalu sekitar sepuluh miliar rupiah. Hal ini menunjukkan minat bisnis dalam kegiatan ini. Dengan demikian, aktivitas pasar lelang mampu memberikan manfaat yang signifikan bagi petani. Di pasar lelang, petani mendapat harga lebih tinggi daripada di pasar reguler. Otomatis, petani juga memperoleh margin keuntungan yang lebih tinggi. Misalnya gula kelapa, petani gula kelapa biasa menjual dengan harga Rp 4.000 per kilo. Di pasar lelang, mereka bisa menjual dengan harga Rp 6.000, yang berarti mereka mendapatkan keuntungan ekstra Rp 2.000 per kilo. Penjualan untuk komoditas ini mencapai 200-300 ton setiap pelaksanaan pasar lelang sehingga keuntungannya mencapai sekitar Rp. 600 juta.

Selain itu, untuk menjadi instrumen dalam mempromosikan pembangunan ekonomi daerah, kerjasama antardaerah juga dapat mewujudkan keunggulan daerah di bidang lain (Sotarauta di Putranto, 2013). Keunggulan lain yang bisa didapat melalui kerjasama antardaerah adalah memperbaiki citra dan identitas daerah. Citra dan identitas sangat penting bagi kerekatan antaradaerah dan popularitas daerah sebagai bagian dari peningkatan daya saing dan daya tawar daerah. Apalagi kerjasama antardaerah juga bisa menciptakan multiplier effect sebagai hasil investasi di kawasan ini. Investasi di daerah akan dapat menghasilkan ekonomi lokal melalui peningkatan aktivitas ekonomi dalam melayani kebutuhan masyarakat dan penyediaan lapangan kerja.

Kerjasama antardaerah juga bermanfaat dalam peningkatan pelayanan publik, seperti kemudahan akses terhadap sumber daya, pasar dan modal oleh pelaku usaha. Selain itu, hal yang menyangkut birokrasi juga bisa dikurangi. Kerjasama antardaerah yang fokus pada promosi dan investasi akan mengembangkan informasi birokrasi dan memungkinkan investor untuk menilai bisnis di wilayahnya. Melalui kerjasama tersebut, pembangunan infrastruktur juga akan semakin terkoordinasi, baik dalam perencanaan maupun pembiayaan. 


\section{RUMUSAN MASALAH}

Keberlanjutan merupakan kunci keberhasilan kerjasama antardaerah. Oleh karena itu, kerjasama antardaerah membutuhkan komitmen yang kuat dari masingmasing daerah. Permasalahan timbul ketika komitmen dibuat untuk melaksanakan program yang telah disepakati tidak diindahkan. Hal ini dipengaruhi oleh dinamika internal yang dialami masing-masing daerah dan intensitas komunikasi yang terjadi antardaerah yang terlibat. Seringkali, manajemen kerjasama regional menjadi macet dalam formalisme. Dengan demikian, banyak peraturan dan kesepakatan dibuat, namun hanya sedikit program yang dilaksanakan bersama (Abdurahman, 2012).

Ego daerah masih menjadi faktor utama masalah kerjasama antardaerah. Kebijakan otonomi daerah sejak tahun 1999, yang diklaim sebagai strategi untuk mendekatkan pelayanan publik kepada masyarakat, cenderung mengembangkan ego lokal. Sebagian besar pemerintah daerah cenderung berorientasi ke wilayahnya sendiri (Sutrisno di Indriya, 2012). Ini juga dialami oleh SAMPAN dalam lima tahun terakhir. Intensitas kegiatan rutin yang dilaksanakan secara bertahap menurun, mengakibatkan pasar lelang, roadshow promosi daerah, serta forum untuk dialog dan koordinasi tidak lagi dilakukan.

Masalah lainnya adalah sistem regional baru di Jawa Tengah yang termuat dalam Peraturan Daerah Propinsi Jawa Tengah No. 6 tahun 2010 tentang Rencana Tata Ruang Wilayah Jawa Tengah. Sistem wilayah di Provinsi Jawa Tengah terbagi menjadi delapan sistem regional. Di bagian barat wilayah pesisir utara Jawa Tengah, dari Kabupaten Batang sampai Kabupaten Brebes, sistem ini terbagi menjadi dua wilayah, yaitu Bregasmalang (Kabupaten Brebes, Kota Tegal, Kabupaten Tegal dan Kabupaten Pemalang) dan Petanglong (Kemasyarakatan Pekalongan, Kabupaten Batang dan Kabupaten Pekalongan). Hal ini tentu akan mempengaruhi orientasi hubungan antardaerah karena masing-masing wilayah memiliki fungsi yang berbeda dalam Rencana Tata Ruang Wilayah Provinsi Jawa Tengah. Bregasmalang memiliki fungsi sebagai pusat layanan di tingkat lokal, provinsi dan nasional, sementara Petanglong hanya berfungsi sebagai pusat layanan di tingkat lokal dan provinsi.

Masalah di atas telah menyebabkan kerjasama antardaerah SAMPAN menjadi stagnan. Seperti yang dikemukakan oleh Pamudji (1985), masalah utama dalam kerjasama antardaerah adalah upaya untuk mendorong pemerintah daerah untuk memprioritaskan kerjasama antardaerah. Langkah ini telah dilakukan oleh Provinsi Jawa Tengah untuk memfasilitasi keberlanjutan kerjasama antardaerah melalui rapat koordinasi, yang diselenggarakan pada hari Kamis, 7 Mei 2015, untuk merevitalisasi kerjasama antardaerah SAMPAN. Pertemuan tersebut bertujuan untuk mengetahui apakah kerjasama antardaerah masih diperlukan oleh daerah, model kerjasama apa dan yang sesuai, serta solusi pendanaan.

Dari uraian di atas, apa yang mendesak untuk diimplementasikan adalah langkah strategis untuk merevitalisasi kerjasama antardaerah. Upaya revitalisasi harus didasarkan pada kondisi lembaga kerjasama. Oleh karena itu, penelitian ini diperlukan untuk menyelaraskan kondisi lembaga kerjasama antardaerah dan faktor-faktor yang mempengaruhi keberlanjutan kerjasama antardaerah.

Berdasarkan uraian kerjasama antardaerah di atas, pertanyaan yang harus dijawab dalam penelitian ini adalah 'Faktor apa saja yang mempengaruhi kinerja kerjasama antardaerah?' Oleh karena itu, tujuan dari penelitian ini adalah untuk mengetahui faktor-faktor yang mempengaruhi stagnasi kerjasama antardaerah SAMPAN. 


\section{KAJIAN LITERATUR}

'Kerjasama' dalam Kamus Bahasa Indonesia didefinisikan sebagai kegiatan atau usaha yang dilakukan oleh beberapa orang atau institusi untuk mencapai tujuan bersama. Dengan kata lain, kerjasama dapat diartikan sebagai interaksi antara beberapa pihak atau lebih yang membentuk suatu kelompok untuk mencapai hasil yang lebih baik. Karena itu, dalam kerjasama, ada unsur kegiatan, pihak yang terlibat, dan tercapainya tujuan. Seperti yang disampaikan Pamudji (1985), tiga elemen penting yang harus ada dalam kerangka kerjasama adalah adanya dua atau lebih pihak yang terlibat, interaksi yang terjadi, dan tujuan yang disepakati bersama.

Menurut Djatmiati (dalam Yodo, 2014: 9-10), kerjasama merupakan interaksi yang bisa dilakukan antarinstansi pemerintah atau antara instansi pemerintah dan pihak swasta. Sementara itu, menurut Patterson (dalam Warsono, 2009), kerjasama antardaerah didefinisikan sebagai "kesepakatan antara dua atau lebih pemerintah untuk mencapai tujuan bersama, memberikan layanan atau memecahkan masalah bersama". Definisi kerjasama antardaerah menyiratkan kepentingan bersama yang mendorong dua atau lebih pemerintah daerah untuk menyediakan layanan bersama atau menyelesaikan masalah secara bersamaan.

Dengan demikian, kerjasama harus mencakup tiga unsur utama, yaitu 1) Dua atau lebih pihak yang bekerjasama; 2) Interaksi; dan 3) Tujuannya. Unsur-unsur ini menggambarkan serangkaian kepentingan yang saling mempengaruhi dan menciptakan interaksi untuk mencapai tujuan bersama. Interaksi yang tidak memiliki tujuan tidak bisa disebut kerjasama. Oleh karena itu, interaksi yang terjadi harus seimbang. Dengan kata lain, interaksi harus saling menguntungkan.

Mengenai faktor-faktor yang mempengaruhi perkembangan jaringan antarpemerintah, ada tujuh variabel yang mempengaruhi efektivitas kerjasama antardaerah (Young, 1992).

1. Transparansi

Dalam kerjasama harus ada transparansi untuk memantau kepatuhan anggotanya. Kerjasama kelembagaan akan efektif jika anggota mematuhi peraturan yang tercantum dalam hak dan kewajiban. Kepatuhan dapat dibangun dengan tiga prinsip yang berbeda, yaitu kemudahan mendeteksi pelanggaran yang dilakukan oleh anggota, kemungkinan sanksi yang akan dikenakan dan jumlah sanksi yang akan diterima. Hal yang paling penting bukanlah besarnya sanksi, namun lebih menekankan pada deteksi pelanggaran oleh anggotanya. Pengenaan sanksi dalam jangka panjang akan melemahkan ikatan kerjasama.

2. Ketahanan

Efektivitas lembaga kerjasama bergantung pada ketahanan dan fleksibilitas dalam menyelesaikan permasalahan yang timbul dalam kerjasama dan fleksibilitas dalam merespon perkembangan yang terjadi antaranggota. Kemitraan yang terlalu rapuh atau kaku tidak akan efektif, karena isu atau perubahan lingkungan sosial dapat meniadakan kerjasama.

3. Transformasi Aturan 
Perubahan peraturan terlalu sering dilakukan sehingga kerjasama tidak efektif. Perubahan peraturan bisa melemahkan efektivitas karena ada kesempatan bagi anggota untuk terus mengubah peraturan yang dianggap memberatkan. Hal ini dapat mengurangi efektivitas kerjasama karena dapat mendorong anggota untuk tidak mematuhi peraturan kerjasama.

4. Kapasitas Anggota

Efektivitas kerjasama ini juga sangat bergantung pada kapasitas anggota untuk menerapkan peraturan yang telah dikeluarkan. Anggota dengan sumber daya yang terbatas akan menjadi kendala dalam pelaksanaan peraturan. Selain itu, kurangnya legitimasi anggota bisa menjadi alasan lain mengapa peraturan menjadi tidak dapat diterapkan dalam yurisdiksi anggota. Legitimasi yang lemah menyebabkan tidak adanya kepatuhan terhadap peraturan yang dikeluarkan. Jika ini terjadi, maka efektivitas kolaborasi akan melemah karena tidak bisa dilaksanakan oleh anggotanya.

5. Distribusi Kekuasaan

Ketidaksetaraan pembagian kekuasaan antaranggota akan membatasi efektivitas kerjasama karena akan ada anggotanya yang sangat dominan dan bisa memaksakan kehendak mereka pada anggota lainnya. Di sisi lain, akan ada anggota yang selalu dalam posisi menolak keinginan dari anggota yang dominan. Anggota yang dominan cenderung mengabaikan peraturan yang tidak sesuai dengan kepentingan mereka. Keseimbangan pembagian kekuasaan antar anggota akan membuat kerjasama lebih efektif karena tidak ada kekuatan besar untuk menolak kesepakatan yang telah dibuat.

6. Interdependensi antar Anggota

Efektivitas kerjasama juga bergantung pada tingkat saling ketergantungan. Ketergantungan muncul ketika tindakan salah satu anggota mempengaruhi kesejahteraan anggota lainnya. Jika anggota saling bergantung, mereka akan sangat peka terhadap perilaku satu sama lain sehingga anggota mempertahankan interaksi. Ketergantungan yang tinggi akan meningkatkan efektivitas kerjasama karena masing-masing anggota saling menjaga kepentingan sesama anggota.

7. Kerangka Intelektual

Kerjasama antardaerah tidak dapat bertahan secara efektif dalam jangka panjang jika struktur kerangka intelektual yang mendasarinya roboh. Efektivitas kerjasama sangat dipengaruhi oleh kekuatan ide dan ide dasarnya.

Sementara itu, Suryani membagi faktor-faktor yang mempengaruhi kinerja kerjasama antardaerah menjadi faktor internal dan eksternal (Suryani, 2006).

1. Faktor Internal

a. Kemampuan manajerial untuk menerjemahkan dan menyelaraskan tujuan organisasi, budaya organisasi, kualitas sumber daya manusia dan kepemimpinan yang efektif.

b. Teknologi, kualitas lingkungan fisik, budaya organisasi, kepemimpinan dan manajemen sumber daya manusia. 
c. Struktur organisasi, manajemen kebijakan, sumber daya manusia, sistem informasi manajemen dan infrastruktur yang dimiliki.

d. Tujuan organisasi, struktur organisasi, sumber daya manusia dan budaya organisasi.

2. Faktor Eksternal

Secara umum, kendala dalam pelaksanaan pembangunan sektoral dan kerjasama regional antara lain: kepentingan dan prioritas yang berbeda; besarnya ketergantungan kepada pemerintah pusat, terutama dalam hal pendanaan; peran pemerintah pusat; masalah pendanaan; dan kurangnya aturan sebagai payung hukum.

Hal-hal yang berpotensi mempengaruhi kinerja kerjasama adalah isu utama yang muncul dalam pelaksanaan otonomi daerah (Kuncoro, 2004): pertama, mengubah egoisme sektoral menjadi fanatisme regional; Kedua, kecenderungan masing-masing daerah untuk memperhatikan daerahnya sendiri dan bahkan saling bersaing dalam berbagai cara; Ketiga, terkait dengan waktu dan kemauan politik karena otonomi daerah; Keempat, masih belum jelas kewenangan pemerintah pusat, provinsi, dan daerah; Kelima, tujuan otonomi daerah adalah memperbaiki pelayanan publik sehingga pelayanan publik diharapkan lebih efektif dan efisien; Keenam, kurangnya koordinasi antarsektor dan antardaerah.

Sejak pelaksanaan otonomi, banyak upaya regionalisasi saat ini masih berhenti di tingkat MoU (Abdurahman, 2005). Hal ini karena pertama, kurangnya kesiapan legislasi yang mendukung proses, terutama yang melekat pada UU otonomi daerah. Kedua, ada kebiasaan menggunakan pola sentralistik yang bertentangan dengan pendekatan desentralisasi, yang mengakibatkan gesekan di lapangan. Akhirnya, ada kekurangan kapasitas di antara pelaku pembangunan untuk menggunakan strategi regionalisasi desentralisasi yang sesuai dengan situasi dan kondisi di tempat.

\section{METODE PENELITIAN}

Penelitian ini menggunakan pendekatan kualitatif-deduktif. Analisis deduktif dilakukan untuk pemilihan indikator awal, yang dianggap mewakili berbagai macam aktivitas kinerja kerjasama antar wilayah, melalui analisis berbagai peraturan dan literatur yang terkait dengan kerjasama antardaerah.

Berdasarkan tujuannya, penelitian ini meliputi penelitian deskriptif, sedangkan berdasarkan berdirinya keilmuannya, penelitian ini meliputi penelitian deduktif. Metode deduktif adalah metode penelitian yang didasarkan pada teori yang telah terbukti di lapangan. Dengan kata lain, para peneliti masuk ke lapangan dengan indikator, parameter, dan variabel yang disintesis dari tinjauan teori dan literatur yang digunakan untuk menjawab pertanyaan penelitian.

Pada teknik pengambilan sampel, pemilihan responden dilakukan dengan teknik purposive sampling dengan kriteria tertentu. Kriterianya adalah 1. Memahami kerjasama antardaerah; dan 2. Aktor kerjasama antardaerah. Responden terdiri dari penyelenggara pemerintahan, akademisi, dan NGO. 
Tabel 4.1 Kriteria Responden

\begin{tabular}{|c|c|c|c|c|}
\hline No & Criteria & Government & Academician/NGO & Others \\
\hline 1 & $\begin{array}{l}\text { Memahami kerjasama } \\
\text { antardaerah }\end{array}$ & $\begin{array}{l}\text { Kasi Bidang Ekonomi Bappeda } \\
\text { Kabupaten Pekalongan }\end{array}$ & $\begin{array}{l}\text { Peneliti P5 Undip } \\
\text { dan Lekad }\end{array}$ & $\begin{array}{l}\text { Tokoh } \\
\text { Masyarakat }\end{array}$ \\
\hline 2 & $\begin{array}{l}\text { Pelaku kerjasama } \\
\text { antardaerah }\end{array}$ & $\begin{array}{l}\text { - Eks analis ekonomi SAMPAN } \\
\text { - Kasi Bidang Ekonomi Bappeda } \\
\text { Pemalang dan Kabid Ekonomi } \\
\text { Bappeda Batang }\end{array}$ & & \\
\hline
\end{tabular}

Sumber: Penulis, 2016

Tabel 4.2 Informasi yang Diperoleh dari Responden

\begin{tabular}{|c|c|c|}
\hline No & Respondent & Information \\
\hline 1 & $\begin{array}{l}\text { Teguh Adi } \\
\text { Bappeda Kabupaten } \\
\text { Pemalang } \\
\text { (3 Agustus 2016) }\end{array}$ & $\begin{array}{l}\text { 1. Sejarah berdirinya SAMPAN. SAMPAN diprakarsai oleh Universitas } \\
\text { Diponegoro pada tahun } 2002 \text {. } \\
\text { 2. Pendanaan SAMPAN dalam bentuk hibah dari masing-masing anggota } \\
\text { sebesar Rp 100.000.000,00. Pendanaan dengan mekanisme hibah ini } \\
\text { menjadi temuan Auditor karena penggunaan dana hibah ini dianggap } \\
\text { tidak jelas dalam hasil dan penerima manfaat. Hal ini karena kegiatan } \\
\text { yang dilakukan SAMPAN tidak di daerah yang memberikan hibah. } \\
\text { 3. Program SAMPAN. } \\
\text { 4. Efektivitas, menurut Pak Teguh, tergantung dari komitmen pemimpinnya. } \\
\text { Seperti program FEDEP yang merupakan program pemerintah provinsi di } \\
\text { mana provinsi menyediakan anggaran daerah, otomatis, daerah juga } \\
\text { memberikan tambahan anggaran untuk pelaksanaan kegiatan FEDEP. } \\
\text { 5. Pendanaan kerjasama antardaerah diusulkan untuk dibiayai oleh } \\
\text { pemerintah provinsi agar tidak melanggar peraturan hibah. } \\
\text { 6. Bidang kerjasama SAMPAN telah meluas ke sektor infrastruktur, seperti } \\
\text { sistem pengembangan air minum dan pengelolaan sampah daerah. }\end{array}$ \\
\hline 2 & $\begin{array}{l}\text { Kabid. Ekonomi, } \\
\text { Bappeda Kabupaten } \\
\text { Batang }\end{array}$ & $\begin{array}{l}\text { 1. Sejarah berdirinya SAMPAN. } \\
\text { 2. Informasi tentang SAMPAN, termasuk bidang kerjasama, bentuk institusi, } \\
\text { masalah yang dihadapi SAMPAN, dan prospek SAMPAN di masa depan. }\end{array}$ \\
\hline 3 & $\begin{array}{l}\text { Kasubbid. Bidang } \\
\text { Ekonomi Bappeda } \\
\text { Kabupaten } \\
\text { Pekalongan } \\
\text { (3 Agustus 2016) }\end{array}$ & $\begin{array}{l}\text { 1. Sejak berdirinya SAMPAN, belum ada peraturan tentang hibah, jadi } \\
\text { pembiayaan kegiatan SAMPAN dengan mekanisme hibah tidak menjadi } \\
\text { masalah dalam penganggaran masing-masing daerah. } \\
\text { 2. Beberapa contoh kerjasama antardaerah menggunakan mekanisme } \\
\text { hibah. Bedanya, hibah untuk kegiatan pendanaan dilakukan oleh daerah } \\
\text { yang menjadi ketua / koordinator kerjasama. }\end{array}$ \\
\hline 4 & $\begin{array}{l}\text { M. Muktiali, SE, MT } \\
\text { Dosen Diponegoro } \\
\text { University, } \\
\text { Semarang } \\
\text { Peneliti pada } \\
\text { Lembaga Kerjasama } \\
\text { Antardaerah } \\
\text { (LEKAD) }\end{array}$ & $\begin{array}{l}\text { 1. Sejarah dan latar belakang berdirinya SAMPAN. } \\
\text { 2. Bentuk dan struktur organisasi organisasi kerjasama antardaerah. } \\
\text { 3. Penelitian tentang manfaat kerjasama antardaerah (SAMPAN, } \\
\text { Barlingmascakeb, Subosukowonosraten). Penelitian ini mengidentifikasi } \\
\text { manfaat kerjasama antardaerah dalam pengembangan ekonomi lokal dan } \\
\text { peningkatan pelayanan publik. } \\
\text { 4. Kendala pendanaan pada kerjasama antardaerah SAMPAN karena } \\
\text { pengelolaan SAMPAN oleh pemerintah daerah masih menggunakan } \\
\text { pendekatan proyek dan pendekatan birokrasi. Diharapkan daerah akan } \\
\text { berinovasi dalam mengembangkan sumber pendanaan untuk kerjasama } \\
\text { antardaerah. }\end{array}$ \\
\hline
\end{tabular}

Sumber: Penulis, 2016

\section{HASIL DAN PEMBAHASAN}

Perkembangan jejaring antarpemerintah di tingkat daerah sangat dipengaruhi oleh beberapa faktor, termasuk bidang kerjasama, komitmen, kapasitas daerah, akuntabilitas, transparansi, dan kejelasan kelembagaan. (Praktikno, et.al, 2005). Pernyataan ini diperkuat oleh Keban dalam Buletin Tata Ruang, edisi Maret-April 2009. Keban mengatakan bahwa pelaksanaan kerjasama antardaerah yang belum optimal 
untuk mendukung peningkatan daya saing daerah dan produk unggulan menjadi penyebab tertinggalnya pembangunan ekonomi daerah. (Keban, 2009).

Terkait dengan faktor-faktor yang mempengaruhi perkembangan jaringan antar pemerintah di tingkat daerah, peran pemerintah pusat juga sangat penting dalam menunjang keberhasilan kerjasama antardaerah. Pemerintah bertindak sebagai fasilitator dalam proses interaksi antardaerah jika kerjasama yang ada belum berfungsi optimal atau bahkan belum terbentuk.

Bagian ini menjelaskan tiga faktor yang menjadi kendala dalam pelaksanaan kerjasama antardaerah SAMPAN yang disusun dari beberapa responden yang berhasil ditemui.

\subsection{Perubahan Peraturan}

Seringnya peraturan yang berubah-ubah mengakibatkan kerjasama berjalan tidak efektif. Adanya perubahan peraturan dapat membuka kesempatan bagi anggota untuk terus mengubah peraturan yang dianggap memberatkan. Hal ini dapat mengurangi efektifitas kerjasama karena dapat mendorong anggota untuk tidak mematuhi peraturan kerjasama. Perubahan ini terutama terkait dengan peraturan yang ditetapkan oleh pemerintah pusat. Perubahan peraturan ini terkait mekanisme pendanaan kerjasama antardaerah.

Implementasi inovasi daerah melalui aliansi pembangunan antardaerah, seperti di Jawa Tengah, melahirkan beberapa kendala, terutama mengenai aspek pendanaan. Kerangka peraturan yang terkait dengan mekanisme pendanaan untuk lembaga kerjasama melalui anggaran pendapatan dan belanja daerah diatur dalam Peraturan Menteri Dalam Negeri No. 37 tahun 2010. Alokasi anggaran untuk kerjasama diarahkan ke mekanisme hibah. Namun, perubahan terhadap ketentuan hibah telah mengakibatkan dinamika dalam beberapa tahun terakhir. Akibatnya, banyak daerah enggan melanjutkan atau menjalin kerjasama antardaerah, terutama dalam bentuk lembaga kerjasama. Ketidakkonsistenan dan lemahnya legalitas dalam mekanisme penganggaran masih membuat daerah sulit bergerak. Dapat dikatakan bahwa masalah pendanaan ini merupakan faktor utama dalam keberlanjutan kerjasama antardaerah. Seperti yang dikemukakan responden dari Pemalang, Bapak Teguh.

Jadi, masalah lain ada tapi tidak akan mematikan aktivitas SAMPAN. Karena yang dibutuhkan SAMPAN adalah dana. Anda bisa melihat lebih lanjut peraturan menteri urusan dalam negeri terkait dengan aturan hibah. Intinya adalah bahwa aturan tersebut membunuh, benar-benar membunuh. Jadi, jika aturan lain tidak membuat atau mengurangi aktivitas. Tapi ini membunuh akarnya. Dengan kata lain, SAMPAN diminta untuk terus berlari namun sumber pendanaannya ditutup. Jadi, SAMPAN sampai sekarang tidak pernah bubar tapi aktivitasnya tidak ada.

Pendapat yang sama juga disampaikan oleh Kepala Sub Bidang Ekonomi Bappeda Kabupaten Pekalongan. Kendala SAMPAN adalah dalam pembiayaan, sejak 2006, SAMPAN sudah mulai hampir tidak aktif. Lalu ada program dari Provinsi Jawa Tengah yaitu Forum Pengembangan Ekonomi dan Promosi Kerja (Forum of Economic Development and Employment Promotion/FEDEP). Pada prinsipnya, kegiatan FEDEP ini juga mempromosikan produk unggulan dari daerah di Jawa Tengah.

Situasi paradoks terjadi lagi ketika di satu sisi pemerintah pusat mendorong daerah tersebut untuk menekan ego daerah dan sektoral melalui kerjasama, 
namun di sisi lain payung peraturan mengenai aspek penganggaran masih menunjukkan kebuntuan. Ambivalensi antara peraturan dan kebijakan ini membuat inovasi lokal memperkuat daya saing regional. Akibatnya, sinergi dan harmonisasi antardaerah dan lintas sektoral yang pada awalnya dapat diwujudkan melalui berbagai kerjasama antardaerah tidak berjalan optimal.

Isu peraturan ini juga muncul karena tumpang tindih antara satu peraturan dengan peraturan lainnya. Di satu sisi, peraturan yang mengatur kerjasama antardaerah, di sisi lain, ada peraturan kontra produktif karena pembiayaan program dengan mekanisme hibah tidak diperbolehkan dilakukan di luar wilayah wilayah yang bersangkutan. Ini seperti yang disampaikan oleh Pak Teguh.

Terkadang aturan yang ada tumpang tindih. Ini tidak berarti kita tidak mau bekerjasama. Banyak kerjasama antardaerah tidak berjalan karena dana dihentikan.

Dasar hukum ini penting untuk keberlanjutan kerjasama antardaerah. Abdurahman mengatakan bahwa tanpa rujukan yang jelas mengenai konsep yang legal dan jelas, terutama mengenai tata kelola dan penganggaran, kerjasama antardaerah akan tetap stagnan. Dengan demikian, selama tidak ada perubahan peraturan dan kebijakan yang tepat, daerah tidak dapat disalahkan jika kerjasama tidak berjalan efektif (Abdurahman, 2014).

Lebih lanjut dijelaskan oleh Abdurahman bahwa konsep kerjasama regional yang ada tidak ditemukan dalam produk peraturan saat ini, terutama pada Peraturan Pemerintah No. 50 tahun 2007. Peraturan pemerintah hanya berfokus pada kerjasama antardaerah yang bersifat equal collaborative dan tidak menyentuh pola inequal collaborative. Kelemahan konseptual ini membuat regulasi yang ada berpotensi menyesatkan. Akibatnya, peraturan yang ada tidak mampu mengakomodasi kerjasama antardaerah yang ada atau bahkan untuk mendorong pertumbuhan inisiatif baru. Banyak aliansi pembangunan antardaerah yang telah bekerja secara efektif sebelum dikeluarkannya peraturan pemerintah dan pedoman teknis untuk pelaksanaan kerjasama regional yang stagnan, termasuk SAMPAN dan banyak kerjasama antardaerah lainnya selama beberapa tahun terakhir.

Dari masalah pendanaan ini, beberapa responden juga mengusulkan konsep tersebut sebagai solusi untuk masalah pendanaan. Pada dasarnya konsep yang disajikan adalah bentuk lembaga kerjasama yang tidak hanya menjalankan program dari pemerintah daerah namun juga dapat menghasilkan pendapatan yang setidaknya menjalankan operasionalnya sendiri. Menurut Muktiali, SAMPAN dapat menghasilkan pendapatan dari kegiatan yang terorganisir, seperti pameran produk daerah, pasar lelang. Pendapatan yang dihasilkan bisa menjadi insentif dan penghargaan bagi institusi SAMPAN sehingga bisa mendorong peningkatan kinerja institusi dan personelnya.

SAMPAN menyelenggarakan pelelangan produk, pasar produk lokal, atau promosi. Dari aktivitas itu SAMPAN bisa memperoleh penghasilan. Penghasilan ini bisa disisihkan sehingga bisa menjadi reward atau insentif bagi manajer regional dan timnya. Semakin besar pendapatan semakin besar insentifnya. Jika perdagangan semakin meluas dan transaksi meningkat, promosi pariwisata membawa lebih banyak wisatawan maka keuntungannya bisa untuk operasionalisasi pengelola daerah. 
Abdullah Sungkar mengemukakan pendapat lain mengenai bentuk kelembagaan SAMPAN dalam mengatasi masalah pendanaan. Menurutnya, SAMPAN tidak hanya membentuk sekretariat bersama namun juga bisa membentuk perusahaan patungan (joint enterprise). Dengan kata lain, perubahan kerjasama kelembagaan antardaerah akan mempengaruhi pola pendanaan SAMPAN. Pendanaan SAMPAN tidak lagi perlu dibebankan pada anggaran daerah.

\subsection{Ketergantungan Antaranggota}

Ketergantungan antaranggota juga akan mempengaruhi keberlanjutan kerjasama. Interdependensi muncul ketika satu anggota mempengaruhi kondisi anggota lainnya, dalam hal ini adalah kondisi ekonomi lokal. Jika anggota saling bergantung, mereka akan sangat sensitif terhadap perilaku masing-masing sehingga setiap anggota akan mempertahankan interaksi.

Ketergantungan ini semakin memudar seiring dengan berkembangnya era otonomi daerah yang mendorong daerah untuk saling bersaing untuk menjadikan daerahnya sebagai daerah yang mandiri. Di era otonomi daerah ini, sistem pemilihan walikota atau bupati juga dilaksanakan secara langsung. Masyaraat langsung memilih pemimpin mereka untuk memerintah daerahnya. Hal ini melahirkan kepala daerah yang tentunya memiliki visi dan misi yang belum tentu sesuai dengan daerah lain dan memiliki komitmen untuk menjalin kerjasama dengan daerah lain. Dengan demikian, rasa saling ketergantungan ini semakin pudar akibat perubahan sistem politik yang ada.

Sudah diketahui bahwa implementasi desentralisasi pemerintahan di Indonesia adalah pengaruh globalisasi. Globalisasi juga membawa perubahan baru, yaitu persaingan yang ketat di semua bidang termasuk persaingan antardaerah. Intensitas persaingan antardaerah semakin meningkat saat pemilihan langsung walikota atau bupati. Melalui pemilihan daerah langsung, dimungkinkan untuk menghindari sinkronisasi kebijakan satu daerah dengan kebijakan daerah lainnya karena faktor kepentingan politik yang berbeda di setiap wilayah. Di sisi lain, menurut Abdurahman (2014), adanya otonomi daerah ini muncul konsekuensi logis yaitu meningkatnya kebutuhan daerah untuk memperkuat daya saing daerah, tidak hanya regional. Hal ini didasarkan pada kenyataan bahwa tidak ada wilayah yang hanya mengandalkan potensi dirinya sendiri.

Selain keterlibatan legislatif dalam kerjasama antardaerah, peran eksekutif, dalam hal ini kepala daerah, juga sangat penting. Banyak penelitian telah mengidentifikasi bahwa faktor ego lokal merupakan faktor dominan yang mempengaruhi kinerja dan keberlanjutan kerjasama antardaerah. Namun, dalam tesis ini, dengan melihat fenomena yang terjadi di wilayah SAMPAN serta informasi yang diperoleh dari responden, faktor ego lokal ini difokuskan pada faktor komitmen pimpinan, dalam hal ini kepala daerah. Ego wilayah yang diindikasikan oleh kebijakan kepala daerah cenderung menekankan kepentingan politiknya. Kepala daerah cenderung menghindari kebijakan yang tidak populer, termasuk menjalin kerjasama dengan daerah tetangga. Hal ini seperti dikatakan Abdullah Sungkar, yang merupakan tokoh masyarakat di Kota Tegal.

Cara berpikir walikota dan bupati saat ini sangat politis. Politis berarti populis. Apa yang di kotanya dianggap megah, hal itu dianggap berhasil. Jadi mereka tidak akan tertarik dengan hal-hal seperti ini (kerjasama antardaerah). Misalnya, Kota Tegal membiayai pengolahan sampah daerah atau membayar biaya tip kepada Kabupaten Tegal yang memiliki lokasi. Orang-orang Kota Tegal akan merespons secara negatif Pemerintah Kota Tegal karena pemerintah 
dinilai tidak mampu mengelola sampah sendiri, hanya menghabiskan anggaran. Kebijakan semacam ini dianggap tidak populer. Walikota tidak akan melakukan itu. Inilah hambatan psikologis regional saat ini.

Dari uraian di atas, dapat dipahami bahwa pemerintah daerah masih belum menganggap kerjasama antardaerah sebagai salah satu inovasi dalam pelaksanaan pembangunan. Salah satu alasannya adalah adanya persaingan dan ego lokal dimana semangat otonomi masih dianggap sempit dan kedaerahan. Setiap daerah memacu perkembangannya sendiri tanpa mempertimbangkan kemampuan dan kebutuhan daerah lain. Kondisi ini menghambat inisiatif daerah untuk bekerjasama dengan daerah lain. Fakta menunjukkan bukti bahwa banyak pelayanan publik yang dikelola melalui kerjasama antardaerah lebih tidak menguntungkan dan disubsidi oleh anggaran daerah sehingga hal ini kurang menarik dalam kerjasama. Pemerintah daerah kemudian memilih untuk bekerjasama dengan sektor swasta karena menganggap kerjasama dengan daerah lain lebih rumit dan rentan terhadap konflik. Sementara itu, daerah hasil pemekaran cenderung lebih enggan bekerjasama dengan daerah lain karena euforia baru tersebut menjadi daerah otonom.

\subsection{Political Will}

Hal-hal yang berpotensi mempengaruhi kinerja kerjasama adalah beberapa isu utama yang muncul dalam pelaksanaan otonomi daerah (Kuncoro, 2004). Salah satunya adalah kemauan politik, baik dari pemerintah pusat maupun dari pemerintah daerah sendiri. Selain perbedaan kepentingan dan kebijakan walikota atau bupati di tingkat pemerintah daerah, seperti yang dijelaskan pada bagian sebelumnya, faktor kemauan politik juga berasal dari legislatif yang juga merupakan salah satu pengambil keputusan dalam pelaksanaan kerjasama antardaerah.

Selain pemerintah pusat, dukungan dari pemerintah daerah juga sangat penting dalam mendukung kinerja dan keberlanjutan kerjasama antardaerah. Dukungan pemerintah daerah tidak hanya berasal dari eksekutif daerah tetapi juga dari legislatif. Saat ini keberadaan dan peran legislatif daerah sangat tinggi dalam perumusan kebijakan internal daerah. Bahkan keterlibatan dewan perwakilan dalam kerjasama antardaerah juga diatur dalam UU No. 23 tahun 2014 tentang Pemerintahan Daerah.

Dalam hal kerjasama antardaerah, legislatif memiliki kewenangan untuk menyetujui rencana kerjasama dengan Daerah lain atau dengan pihak ketiga yang membebani anggaran daerah. Namun, yang terjadi adalah legislatif menilai setiap anggaran yang dikeluarkan oleh pemerintah harus membawa hasil nyata bagi daerah tersebut. Hasil sebenarnya menurut mereka adalah dampak yang bisa langsung dimanfaatkan masyarakat terutama masyarakat di daerah. Kerjasama antardaerah yang telah didanai dianggap tidak memberikan hasil yang signifikan. Ini seperti pernyataan Muktiali yang dikutip dari wawancara pada 2 Maret 2017.

Peran dan fungsi kerjasama antardaerah belum sepenuhnya dipahami, terutama oleh dewan perwakilan. Saya masih ingat, mereka menginginkan hasil instan. Dengan demikian, legislatif berpendapat bahwa setiap rupiah yang dihabiskan harus bisa membawa manfaat nyata dan cepat. Singkatnya, daerah punya modal, sudah membentuk lembaga tapi manfaatnya tidak cukup signifikan. Jadi mereka sering memutuskan untuk tidak menyetujui kegiatan kerjasama antardaerah. 
Pada dasarnya, persetujuan anggota dewan mengenai pelaksanaan kerjasama antardaerah terkait dengan alokasi dana dan pemanfaatan aset lokal untuk kepentingan kegiatan tersebut. Untuk mengatasi masalah tersebut, menurut Antonius Tarigan, perlu ada pemahaman dari legislatif mengenai penggunaan anggaran untuk kerjasama antardaerah. Tarigan mengatakan bahwa kerjasama regional yang membebani daerah dan masyarakat harus mendapat persetujuan Dewan Perwakilan Rakyat Daerah (DPRD) dengan ketentuan bahwa biaya kerjasama belum dianggarkan dalam anggaran daerah atau penggunaan aset daerah. Namun, kerjasama regional yang dilakukan untuk menunjang tugas dan fungsi instansi terkait dan biayanya sudah dianggarkan dalam APBD maka tidak perlu mendapat persetujuan dari dewan perwakilan (Tarigan, 2009). Berdasarkan pernyataan Tarigan, polemik tentang persetujuan legislatif untuk kegiatan kerjasama antardaerah tidak boleh terjadi dalam kerjasama antardaerah.

\section{SIMPULAN}

Kerjasama antardaerah merupakan salah satu strategi dalam Pembangunan Ekonomi Daerah. Pelaksanaan kerjasama antardaerah memiliki kelebihan dan kekurangan sesuai dengan karakteristik kerjasama, yang meliputi jumlah daerah yang terlibat, bentuk kerjasama, bidang kerjasama dan mekanisme pendanaan.

SAMPAN sebagai salah satu bentuk kerjasama antardaerah memiliki dinamika keberlanjutan yang juga dialami oleh daerah lain. SAMPAN saat ini stagnan, meski pada awal terbentuk hingga sebelum stagnan, SAMPAN berkontribusi dalam pengembangan ekonomi lokal bagi daerahnya. Masalah ego dan pendanaan merupakan faktor utama dalam keberlanjutan SAMPAN yang merupakan dampak dari transformasi peraturan dan kurangnya saling ketergantungan antardaerah. Kendala ini merupakan faktor yang perlu dipertimbangkan dalam strategi untuk mengaktifkan kembali kerjasama antardaerah SAMPAN.

Beberapa catatan tentang kelemahan kerjasama antardaerah yang dialami oleh SAMPAN dapat dijelaskan sebagai berikut. Pertama, kerjasama antardaerah harus menjadi prioritas kebijakan pembangunan oleh masing-masing walikota dan bupati. Ego lokal yang merupakan faktor utama keberlanjutan kerjasama antardaerah harus diabaikan demi pengembangan yang lebih luas. Kedua, bentuk lembaga kerjasama sangat berpengaruh terhadap mekanisme pendanaan. Sejauh ini, dana untuk kerjasama antardaerah masih bergantung pada anggaran daerah. Oleh karena itu, bentuk mekanisme kerjasama dan pendanaan untuk kerjasama antardaerah harus dipertimbangkan pada awal kesepakatan, didukung oleh landasan hukum sehingga tidak menjadi masalah di masa depan bagi seluruh daerah.

Meski demikian, kerjasama antardaerah merupakan keniscayaan yang harus dilakukan oleh daerah dalam melaksanakan program pembangunan. Apalagi ketentuan ini telah diatur dalam undang-undang pemerintah daerah yang semakin membuka peluang kerjasama, baik bersifat wajib maupun bersifat sukarela. Paling tidak daerah harus melakukan kerjasama wajib, yaitu kerjasama pembangunan yang memiliki cakupan lintas batas dan memiliki eksternalitas berisiko tinggi sehingga mereka harus bekerjasama untuk menangani masalah bersama. Sementara itu, kerjasama sukarela bisa menjadi alternatif untuk membangun kerjasama antardaerah, baik bilateral maupun multilateral.

Di sisi lain, otonomi daerah menghadirkan tantangan bagi daerah untuk menjalin kerjasama. Ego daerah yang tinggi dalam menjalankan pemerintahan merupakan hambatan di era otonomi di Indonesia. Hal ini dipengaruhi oleh dinamika politik di 
daerah di mana sangat sulit menerapkan program pembangunan jangka panjang dan berkelanjutan secara konsisten, terutama jika terjadi pergantian kepala daerah. Di sinilah pemahaman tentang perencanaan pembangunan dan peran komitmen kepala daerah dalam kerjasama antardaerah diperlukan.

Bagaimanapun, kerjasama antardaerah telah memberikan banyak manfaat bagi daerah, baik secara langsung maupun tidak langsung, terutama terhadap pembangunan ekonomi daerah dan daerah. Di satu sisi, kerjasama akan memperkuat kerekatan daerah dalam mengatasi permasalahan di daerah, di sisi lain, kerjasama akan memperkuat daya saing semua daerah agar bisa bersaing di pasar ekonomi yang lebih luas.

\section{DAFTAR PUSTAKA}

Abdurahman, Benjamin, 2005, Pemahaman Dasar Regional Management \& Regional Marketing, Jakarta: IAP.

Abdurahman, Benjamin, 2014. Kelemahan Regulasi dan Kebijakan Tumpulkan Inovasi Pembangunan Daerah - Telaah Kritis Regulasi dan Kebijakan terkait Kerjasama Antardaerah di Era Post-Reformasi, Jurnal Pembangunan Daerah, Vol. II, Edisi 2.

Astika, Indriya Ryastra, 2012, Evaluasi Keberhasilan Kerjasama Antardaerah dalam Peningkatan Pengelolaan Infrastruktur Studi Kasus: Infrastruktur Transportasi Metropolitan Yogyakarta, Jurnal Perencanaan Wilayah dan Kota SAPPK No. 1. Bandung.

Dunn, William N., 1998, Pengantar Analisis Kebijakan Publik, Yogyakarta: Gadjah Mada University Press.

Goss, Sue, 2001, Making Local Governance Work: Networks, Relationship and the Management of Change, New York: Palgrave.

Keban, Yeremias T., 2009, Strategi Membangun “Daya Saing” Daerah Tertinggal. Buletin Tata Ruang Edisi Maret-April 2009. Jakarta.

Kuncoro, Mudrajad, 2012, Perencanaan Daerah: Bagaimana Membangun Ekonomi Lokal, Kota, dan Kawasan, Jakarta: Salemba Empat.

Moekijat,1995, Analisis Kebijaksanaan Publik. Mandar Maju. Bandung.

Muhadjir, Noeng, 2000, Metodologi Penelitian Kualitatif, Yogyakarta: Rake Sarasin.

Muktiali, Mohammad, 2009, Manfaat Kerjasama Daerah Terhadap Ekonomi Regional dan Pelayanan Publik: Suatu Tinjauan Manfaat Berdasarkan Impact Chain Analysis Terhadap KAD di Wilayah Jawa Tengah. http://eprints.undip.ac.id/2425/1/Manfaat Kerjasama Daerah Terhadap Ekonomi Regional dan.pdf, (accessed on July 15, 2016).

Pamudji, S., 1985, Kerjasama Antardaerah dalam Rangka Pembinaan Wilayah, Jakarta: Bina Aksara.

Pratikno, (Ed)., 2007, Kerjasama Antardaerah: Kompleksitas dan Tawaran Format Kelembagaan, Yogyakarta. Jogja Global Media.

Pratikno, et.al., 2005, Model Kerjasama Antardaerah, Yogyakarta: Program S2 Politik Lokal dan Otonomi Daerah. 
Putranto, Adhitya Eka, 2013, Peran BKAD Subosukowonosraten dalam Kerjasama Antardaerah, Jurnal Pembangunan Wilayah dan Kota Vol. 9 No. 2, Semarang: PWK Undip.

Supriyadi R., Ery, 2007, Telaah Kendala Penerapan Pengembangan Ekonomi Lokal: Pragmatisme dalam Praktik Pengembangan PEL, Jurnal Perencanaan Wilayah dan Kota Vol. 18 No. 2 Agustus 2007, Bandung: SAPPK ITB.

Tarigan, Antonius, 2009, Kerjasama Antardaerah (KAD) untuk Peningkatan Penyelenggaraan Pelayanan Publik dan Daya Saing Wilayah, Buletin Tata Ruang Edisi Maret-April 2009, Jakarta: Sekretariat Im Pelaksana BKPRN.

Warsono, Hardi, 2009, Regionalisasi dan Manajemen Kerjasama Antardaerah (Studi Kasus Dinamika Kerjasama Antardaerah yang Berdekatan di Jawa Tengah), Yogyakarta: Program Doktor Ilmu Administrasi Negara, Universitas Gadjah Mada.

Yodo, S., 2014, Aspek Hukum Ekonomi Dalam Kerjasama Daerah, Yogyakarta: Genta Publishing.

Young, Oran R., 1992, The Effectiveness of International Institution: Hard Cases and Critical Variables, Dalam James N. Rosenau dan ernst-Otto Czempiel, ed, Governance without Government: Order and Change in World olitics. Cambridge University Press. 